\title{
SESKUITERPEN FURANODIENON DARI RIMPANG Curcuma xanthorrhiza DAN AKTIVITAS ANTIBAKTERINYA
}

\author{
Hartiwi Diastuti ${ }^{1,2}$, Yana Maolana Syah ${ }^{1}$, Lia Dewi Juliawaty ${ }^{1}$, Marlia Singgih ${ }^{3}$ \\ ${ }^{1}$ Kelompok Penelitian Kimia Bahan Alam, Fakultas MIPA, Institut Teknologi Bandung. \\ ${ }^{2}$ Program Studi Kimia, Universitas Jenderal Soedirman Purwokerto. \\ ${ }^{3}$ Sekolah Farmasi, Institut Teknologi Bandung \\ Email : hartiwidiastuti@yahoo.com
}

\begin{abstract}
ABSTRAK
Curcuma xanthorrhiza dikenal sebagai tanaman obat Indonesia, rimpangnya sering digunakan dalam pengobatan tradisional. Penelitian ini bertujuan untuk mengisolasi senyawa seskuiterpen dari rimpang Curcuma xanthorrhiza dan menguji aktivitas antibakterinya. Isolasi senyawa dilakukan dengan kromatografi kolom vakum cair dan kromatografi radial. Identifikasi struktur dilakukan secara spektroskopi (FTIR (Fourier Transfrom Infra Red), NMR (Nuclear Magnetic Resonance) 1D dan 2D, serta MS (Mass Spectroscopy)). Uji antibakteri dilakukan dengan metode mikrodilusi, terhadap beberapa bakteri uji yaitu Escherichia coli, Pseudomonas aeruginosa, Bacillus subtilis dan Staphylococcus aureus,. Isolat yang diperoleh berupa minyak tak berwarna yang teridentifikasi sebagai senyawa seskuiterpen furanodienon. Furanodienon menunjukkan aktivitas antibakteri dengan nilai MIC dan MBC 125,0 dan 250,0 $\mu \mathrm{g} / \mathrm{mL}$.
\end{abstract}

Kata kunci : Furadienon, Curcuma xanthorrhiza, antibakteri

\section{FURANODIENONE SESQUITERPENE FROM Curcuma xanthorrhiza RHIZOMES AND ITS ANTIBACTERIAL ACTIVITY}

\begin{abstract}
Curcuma xanthorrhiza has known as medicine plant of Indonesia which its rhizomes use to traditional medicine. The aim of this research was to isolate and indentify the sesquiterpene compounds from Curcuma xanthorrhiza rhizomes and to examine its antibacterial activity. Isolation was carried out by using vacuum liquid chromatography and radial chromatography. The structure was determined by spectroscopic technique ((FTIR (Fourier Transfrom Infra Red), NMR (Nuclear Magnetic Resonance), and MS (Mass Spectroscopy)). Antibacterial test was carried out by using microdillution methods and evaluated against bacteria Escherichia coli, Pseudomonas aeruginosa, Bacillus subtilis, and Staphylococcus aureus. The result showed that the isolate was a colourless oil which was identified as furanodienone-type sesquiterpene. Furanodienone have antibacterial activity, with MIC and MBC values of 125.0 and $250.0 \mu \mathrm{g} / \mathrm{mL}$, respeetively.
\end{abstract}

Key words : Furanodienon, C. xanthorrhiza, antibacterial.

\section{PENDAHULUAN}

Pencemaran makanan oleh mikroba patogen merupakan salah satu penyebab penyakit yang menginfeksi manusia. Penyebaran penyakit dengan cara ini telah menjadi perhatian serius, bukan saja di Indonesia, melainkan juga untuk negara-negara maju seperti Amerika Serikat. Usaha-usaha untuk menekan penyebaran ini lazimnya adalah melalui 
penggunaan bahan pengawet sintetik ke dalam makanan. Namun demikian, keprihatinan akan kemungkinan pengaruh negatif terhadap kesehatan karena penggunaan bahan pengawet sintetik tersebut telah membangkitkan kembali penggunaan senyawa-senyawa antimikroba alami. Beberapa kajian untuk tujuan ini telah muncul pada laporanlaporan ilmiah sebelumnya. Berbagai kelompok bahan fitokimia tumbuhtumbuhan, antara lain alkaloid, kumarin, flavonoid, isoflavonoid, dan terpenoid, ternyata dapat memberikan efek biologis sebagai antibiotik dengan konsentrasi minimum hambatan pertumbuhan (Minimum Inhibitory Concentrations $=$ MIC) dalam satuan $\mu \mathrm{g} / \mathrm{mL}$ (Saleem, et al., 2010).

Curcuma xanthorrhiza atau dikenal dengan temulawak adalah salah satu tumbuhan asli Indonesia yang sering digunakan sebagai obat tradisional, terutama pada bagian rimpangnya. Lebih dari 50 resep jamu menggunakan rimpang $C$. xanthorrhiza untuk pengobatan berbagai penyakit (Achmad, et al., 2008 dan Tilaar, et al., 2010). Rimpang C. xanthorrhiza dimanfaatkan juga sebagai rempah penyedap masakan, pemberi warna kuning pada makanan, dibuat minuman untuk menjaga kesegaran badan, serta bahan baku kosmetik (Dalimartha, 2007).

Ciri kimia utama dari tumbuhan ini adalah terdapatnya senyawa-senyawa metabolit sekunder turunan diarilheptan atau kurkuminoid dan senyawa terpenoid golongan seskuiterpen (Ravindran, et al., 2007)

Penelitian aktivitas biologi $C$. xanthorrhiza terhadap serbuk, ekstrak kasar, minyak atsiri dan senyawa hasil isolasi terutama senyawa kurkuminoid sudah banyak dilakukan, dan masih merupakan objek studi yang terus dikembangkan. Aktivitas biologi yang menarik dari ekstrak dan minyak atsiri tumbuhan ini telah banyak dilaporkan, seperti antiinflamasi, antikolesterol, antikanker, dan antimikroba (Achmad, et al, 2008).

Aktivitas biologi beberapa senyawa terpenoid seskuiterpen rimpang $C$. xanthorrhiza juga telah dilaporkan. Senyawa seskuiterpen $a r$-kurkumen yang merupakan salah satu senyawa utama rimpang $C$. xanthorrhiza, dilaporkan dapat menurunkan kadar kolesterol dan trigliserida dalam darah tikus percobaan (Yasni, et al., 1994). Senyawa-senyawa ar-kurkumen, ar-turmeron dan santorizol (Gambar 1) dari rimpang $C$. xanthorrhiza menunjukkan aktivitas antitumor terhadap Sarcoma 180 pada tikus (Itokawa, et al., 1985). Senyawa germakron (Gambar 1) pada rimpang $C$. xanthorrhiza mampu memberikan efek hipotermik yang diberikan secara oral pada tikus percobaan (Yamazaki, et al., 1988)

Santorizol sebagai salah satu senyawa penting pada rimpang $C$. xanthorrhiza dilaporkan memiliki aktivitas biologi yang tinggi terhadap beberapa bakteri Streptococcus penyebab dental caries, aktivitas biologi yang lemah terhadap bakteri penyebab periodontis, yaitu Actinomyces viscous dan Porphyromonas gingivalis. Beberapa spesies Lactobacillus resisten terhadap santorizol (Hwang, et al., 2000) Beberapa hasil penelitian melaporkan juga bahwa santorizol memiliki aktivitas anticandida, anti-Malassezia (Rukayadi and Hwang, 2007), aktivitas anti metastasis pada tikus yang mengalami tumor (Choi, et al, 2005) serta mempunyai efek antiproliferatif pada sel Hepatoma HepG2 (Handayani, 2008). 
<smiles>CC(C)=CCC[C@H](C)c1ccc(C)cc1</smiles>

ar- Kurkumen<smiles>CC(C)=CC(=O)C[C@@H](C)c1ccc(C)cc1</smiles>

ar-Turmeron<smiles>CC(C)=CCC[C@H](C)c1ccc(C)c(O)c1</smiles>

Santorizol<smiles>CC(C)=CCC(=O)C(CC=C(C)C)=C(C)C</smiles>

Germakron

Gambar 1. Beberapa senyawa seskuiterpen dari rimpang C. xanthorrhiza

Penelitian aktivitas antimikroba pada senyawa terpenoid rimpang $C$. xanthorrhiza masih sangat terbatas. Hal tersebut mendorong peneliti untuk melakukan kajian lebih lanjut mengenai sifat antimikroba senyawa seskuiterpen dari rimpang C. xanthorrhiza.

\section{METODE PENELITIAN}

\section{Bahan Penelitian}

Bahan tumbuhan yang digunakan adalah rimpang $C$. xanthorrhiza yang diperoleh dari daerah Surakarta, Jawa Tengah. Bakteri yang digunakan meliputi bakteri gram negatif Escherichia coli dan Pseudomonas aeruginosa serta bakteri gram positif Bacillus subtilis dan Staphylococcus aureus. Media Muller Hinton Broth (MHA) dan Muller Hinton Agar (MHB), serta pelarut organik teknis yang didestilasi : $n$-heksana, kloroform, etil asetat, aseton dan metanol.

\section{Prosedur Penelitian}

\section{Ekstraksi dan Pemurnian}

Serbuk rimpang C. xanthorrhiza $(2,0 \mathrm{~kg})$ dimaserasi dengan aseton ( 7 L) selama $3 \times 24$ jam. Ekstrak aseton hasil maserasi dipekatkan pada tekanan rendah menggunakan rotary evaporator. Ekstrak aseton pekat selanjutnya diekstraksi partisi dengan n-heksana: metanol (1:1) g. Ekstrak $n$-heksana (20 g) selanjutnya difraksinasi dengan kromatografi kolom vakum, menggunakan fasa diam silikagel dan eluen (fasa gerak ) $n$-heksana, campuran dari $n$-heksana:kloroform pada berbagai perbandingan, kloroform, dan etilasetat. Hasil fraksinasi kemudian dipisahkan kembali dan dimurnikan melalui kromatografi radial dengan eluen $n$-heksana: kloroform (9:1). Isolat yang diperoleh diuji kemurniannya dengan KLT (Kieselgel $60 \mathrm{GF}_{254}$ ) menggunakan tiga sistem eluen yang berbeda. Isolat murni selanjutnya ditentukan strukturnya dengan spektrometer FTIR (Perkin Elmer Spectrum one), NMR 1D $\left({ }^{1} \mathrm{H}(500 \mathrm{Mhz})\right.$ dan ${ }^{13} \mathrm{C}$ (125 MHz) Agilent DD2), NMR 2D (HMQC=Heteronuclear Multiple Quantum Coherence dan $\mathrm{HMBC}=$ Heteronuclear Multiple Bond Coherence) dan spectrometer massa (MS).

\section{Uji Aktivitas Antibakteri}

Uji aktivitas biologi isolat murni dilakukan terhadap beberapa bakteri yaitu 
E. coli, $P$. aeruginosa, B. subtilis dan $S$. aureus secara in vitro dengan metode mikrodilusi (microdillution methods). Uji ini dilakukan untuk mengetahui konsentrasi hambat minimum (Minimum Inhibitory Concentration = MIC) dari isolat murni terhadap bakteri uji. Setelah MIC diketahui uji dilanjutkan dengan menentukan konsentrasi bunuh minimum ( minimum bactericidal concentration $=$ MBC) isolat murni terhadap bakteri uji. (Kamazeri, et al., 2012).

Uji antibakteri meliputi tiga tahap yaitu:

1) Pembuatan suspensi mikroba.

Bakteri dibiakkan selama 24 jam pada suhu $37{ }^{\circ} \mathrm{C}$ pada kondisi aerob pada medium agar. Bakteri disuspensikan dalam larutan $\mathrm{NaCl} 0,9 \%$ (b/v), kemudian disetarakan dengan standar 0,5 Mc Farland (diperkirakan 1-2 x $10^{6}$ sel bakteri $/ \mathrm{mL}$ ).

2) Penentuan konsentrasi hambat minimum

Dibuat larutan uji dengan konsentrasi $1000 \mu \mathrm{g} / \mathrm{mL}$, Sebanyak 200 $\mu \mathrm{L}$ media cair MHB dimasukkan ke dalam setiap sumuran mikroplat (96 wells). Ke dalam sumuran pertama ditambahkan $200 \mu \mathrm{L}$ larutan uji. Seri konsentrasi larutan dilakukan dengan memindahkan $200 \mu \mathrm{L}$ larutan dari sumuran kesatu ke sumuran kedua, dari sumuran kedua diambil lagi sebanyak $200 \mu \mathrm{L}$ dan dimasukkan ke sumuran ketiga, hal yang sama dilakukan sampai ke sumuran kedelapan. Jumlah larutan dalam masing-masing sumuran adalah $200 \mu \mathrm{L}$. Selanjutnya ke dalam masingmasing sumuran dimasukkan $10 \mu \mathrm{L}$ suspensi mikroba. Dua sumuran berikutnya masing-masing digunakan untuk dua larutan kontrol. Untuk kontrol pertama sumuran diisi dengan $200 \mu \mathrm{L}$ media cair dan $10 \mu \mathrm{L}$ suspensi mikroba (growth control), sedangkan untuk kontrol kedua sumuran hanya diisi dengan $200 \mu \mathrm{L}$ media cair (sterility control). Mikroplat selanjutnya diinkubasi pada suhu $37{ }^{\circ} \mathrm{C}$ selama 24 jam untuk bakteri dan suhu $25{ }^{\circ} \mathrm{C}$ selama 48 jam untuk jamur. Pertumbuhan mikroba ditentukan dengan menggunakan universal microplate reader pada panjang gelombang $600 \mathrm{~nm}$. Nilai konsentrasi hambat minimum (MIC) adalah konsentrasi terendah yang dapat menghambat pertumbuhan mikroba. Kontrol positif yang digunakan pada penelitian ini adalah kloramfenikol.

3) Penentuan konsentrasi bunuh minimum (MBC)

Untuk menentukan MBC, semua larutan uji yang tidak memperlihatkan adanya pertumbuhan mikroba pada tahap 2, diinokulasikan ke dalam media padat Mueller Hinton Agar (MHA) dan diinkubasi pada suhu $37{ }^{\circ} \mathrm{C}$ selama 24 jam, selanjutnya pertumbuhan mikroba diamati. Konsentrasi terendah dari larutan uji yang dapat membunuh semua mikroba dinyatakan sebagai MBC.

\section{HASIL DAN PEMBAHASAN}

Hasil ekstraksi serbuk rimpang $C$. xanthorrhiza $(2,0 \mathrm{~kg})$ dengan aseton diperoleh ekstrak aseton pekat berupa gum berwarna coklat (146 g). Sebanyak $100 \mathrm{~g}$ ekstrak aseton diekstraksi partisi dengan $n$-heksana: metanol (1:1), diperoleh ekstrak $n$-heksana sebanyak $65 \mathrm{~g}$. Ekstrak $n$-heksana (20 g) selanjutnya difraksinasi dengan kromatografi kolom vakum, fasa diam silikagel dengan eluen berturut-turut $n$-heksana, campuran $n$ heksana:kloroform pada berbagai perbandingan (9: 1 sampai 1 : 9), kloroform dan etilasetat. Hasil fraksinasi 


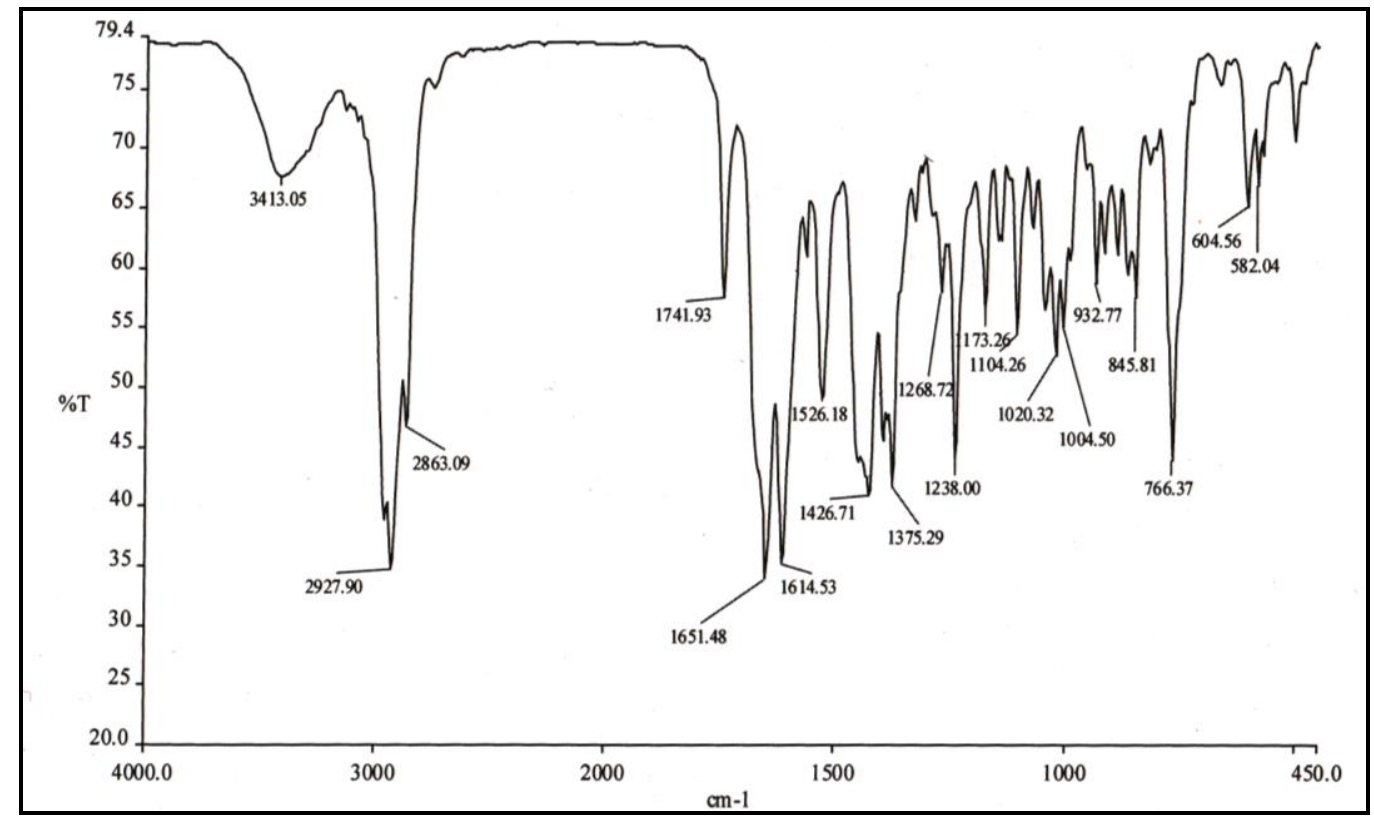

Gambar 2. Spektrum FTIR isolat murni

diperoleh 6 fraksi utama yaitu F1-F6 masing-masing F1(0,5 g), F2 (8,6 g), F3 $(0,9 \mathrm{~g}), \mathrm{F} 4(1,1 \mathrm{~g}), \mathrm{F} 5(1,7 \mathrm{~g})$ dan F6 (2,9 g). Hasil pemurnian dari F4 dan F5 melalui kromatografi radial dengan eluen $n$-heksana: kloroform $(9: 1)$ diperoleh senyawa murni berupa minyak tak berwarna sebanyak $25 \mathrm{mg}$. Uji kemurnian dengan KLT menggunakan tiga sistem eluen yang berbeda yaitu $n$ heksana:kloroform $\quad(9: 1), \quad n$ heksana:kloroform (3:2) dan n-heksana: etilasetat (4:1), masing-masing menunjukkan satu noda dengan nilai $\mathrm{Rf}$ berturut-turut 0,$33 ; 0,50$ dan 0,80 . Hal ini mengindikasikan bahwa isolat sudah cukup murni.

Isolat murni selanjutnya diidentifikasi struktur kimianya secara spektroskopi, yaitu menggunakan spektrometer FTIR, NMR $1 \mathrm{D}\left({ }^{1} \mathrm{H}\right.$ dan ${ }^{13} \mathrm{C}$ ), NMR 2D (HSQC dan HMBC dan MS.

Spektrum FTIR (Gambar 2) mengindikasikan bahwa isolat mengandung gugus karbonil ( $\bar{v}_{\text {maks }} 1741$ $\left.\mathrm{cm}^{-1}\right)$, ikatan $\mathrm{Csp}^{3}-\mathrm{H}\left(\bar{v}_{\text {maks }} 2927\right.$ dan $\left.1426 \mathrm{~cm}^{-1}\right)$, sistem alkena terkonjugasi $\left(\bar{v}_{\text {maks }} 1614 \mathrm{~cm}^{-1}\right)$ dan enol eter $\left(\bar{v}_{\text {maks }} 1651\right.$ $\left.\mathrm{cm}^{-1}\right)$.

Spektrum ${ }^{1} \mathrm{H}-\mathrm{NMR} \quad(500 \mathrm{MHz}$, $\left.\mathrm{CDCl}_{3}\right)$ menunjukkan 18 sinyal proton (Gambar 3) meliputi : tiga sinyal metil $(\mathrm{CH} 3)$ yaitu $\delta 1,31(3 \mathrm{H}, \mathrm{s}, \mathrm{H}-15), \delta 2,00$ $(3 \mathrm{H}, \mathrm{s}, \mathrm{H}-14), \delta 2,14(3 \mathrm{H}, \mathrm{s}, \mathrm{H}-13)$, tiga sinyal metilen $(\mathrm{CH} 2) \delta 2,18(2 \mathrm{H}, \mathrm{q}, \mathrm{H}-$ $2), \delta 2,47(2 \mathrm{H}, \mathrm{t}, \mathrm{H}-3), \delta 3,71(2 \mathrm{H}, \mathrm{s}, \mathrm{H}-$ $9)$, dan tiga sinyal metin $(\mathrm{CH})$ yaitu $\delta$ $5,18(1 \mathrm{H}, \mathrm{dd}, \mathrm{H}-1), \delta 5,81(1 \mathrm{H}, \mathrm{s}, \mathrm{H}-5)$ dan $\delta$ 7, $08(1 \mathrm{H}, \mathrm{s}, \mathrm{H}-12)$.

Sedangkan spektrum ${ }^{13} \mathrm{C}-\mathrm{NMR}$ (Gambar 4) memperlihatkan 15 sinyal karbon yang terdiri dari 3C-metil $\left(\mathrm{CH}_{3}\right)$ dengan $\delta$ 9,05 (C-13), $\delta$ 15,78 (C-15), dan $\delta 18,91$ (C-14), 3C-metilen $\left(\mathrm{CH}_{2}\right)$ dengan $\delta$ 26,44 (C-2), $\delta$ 40,60 (C-3), dan $\delta 41,69$ (C-9), 3C-metin $(\mathrm{CH})$ dengan $\delta$ $130,32(\mathrm{C}-1), \delta 132,44(\mathrm{C}-5)$ dan $\delta$ 138,06 (C-12), serta 6C-kuarterner yang meliputi 1C-karbonil dengan $\delta 189,90$ (C-6), dan 5C-non karbonil ( $\delta$ 122,12, (C-7), $\delta$ 123,70, (C-11), $\delta$ 135,59 (C-10), dan $\delta 156,60(\mathrm{C}-8)$. 
Seskuiterpen furanodienon dari rimpang Curcuma Xanthorrizha... (Hartiwi Diastuti, dkk)

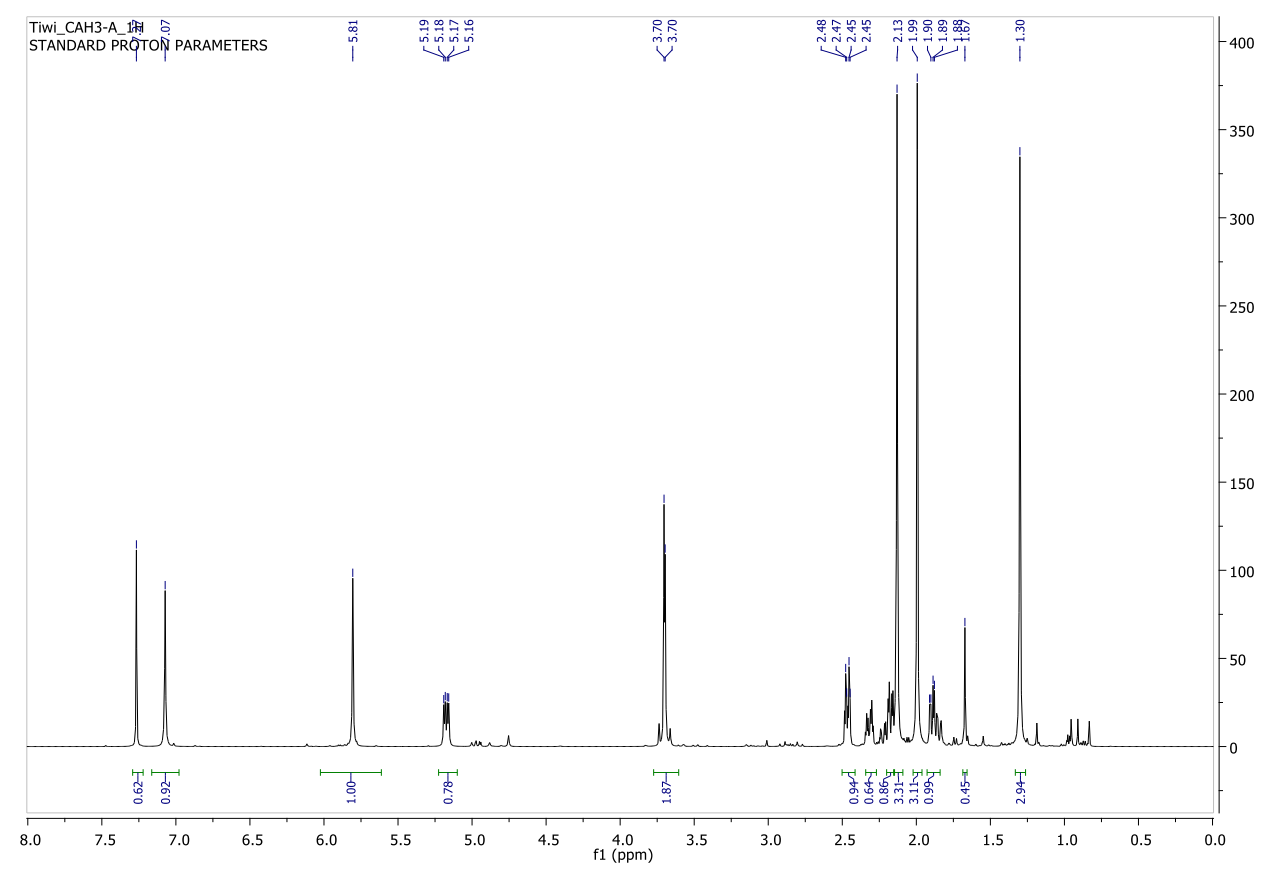

Gambar 3. Spektrum ${ }^{1} \mathrm{H}-\mathrm{NMR}$ isolat murni

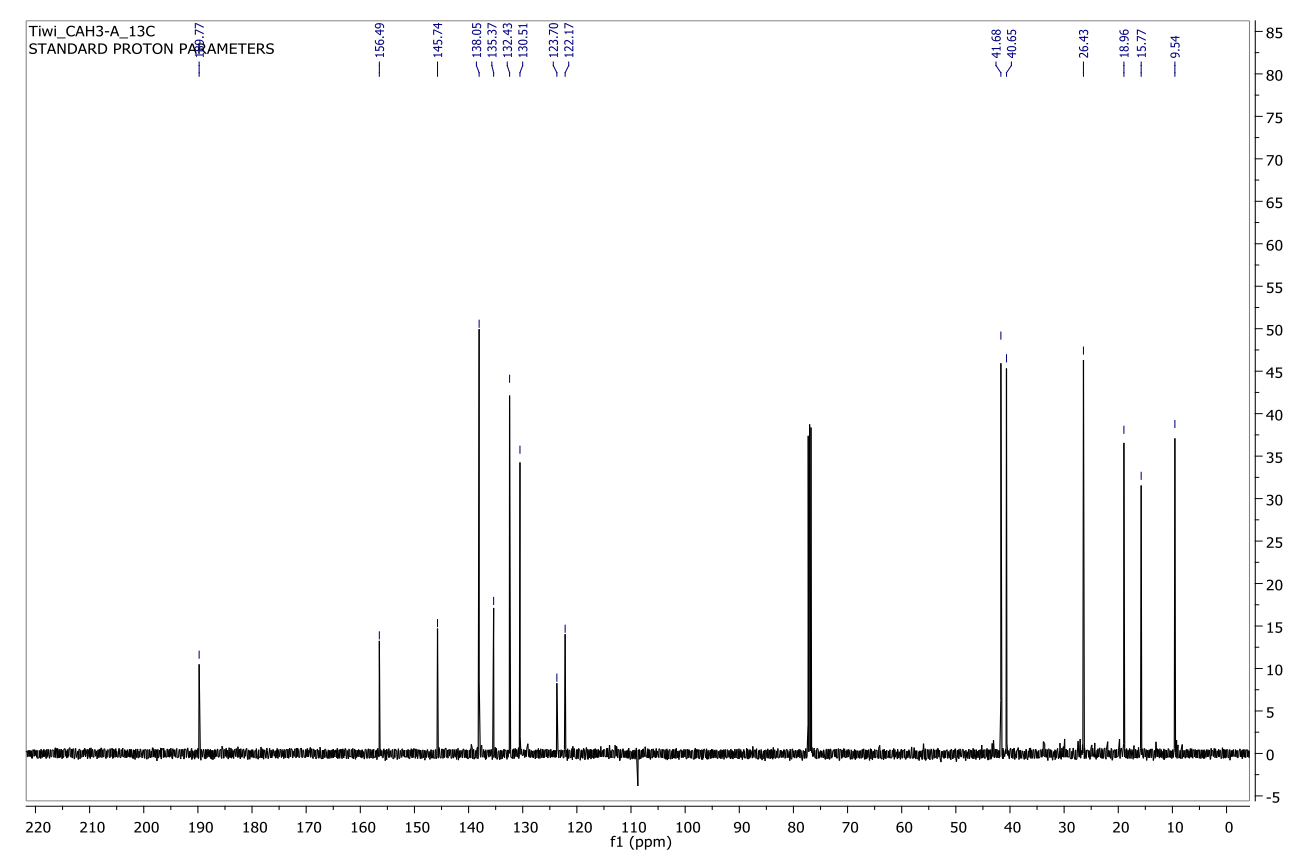

Gambar 4. Spektrum ${ }^{13} \mathrm{C}-\mathrm{NMR}$ isolat murni

Korelasi ikatan antara atom karbon dan proton dalam satu ikatan ditentukan dengan melihat spektrum NMR 2D-HMQC, sedangkan spektrum NMR 2D-HMBC digunakan untuk melihat adanya korelasi dua atau tiga ikatan antara proton dengan karbon. Jadi dengan menggunakan spektrum NMR 2D dapat diketahui posisi atom-atom karbon dan proton dalam suatu senyawa atau molekul. Spektrum NMR 2D-HMQC dan MBC disajikan pada Gambar 5 dan Gambar 6. 


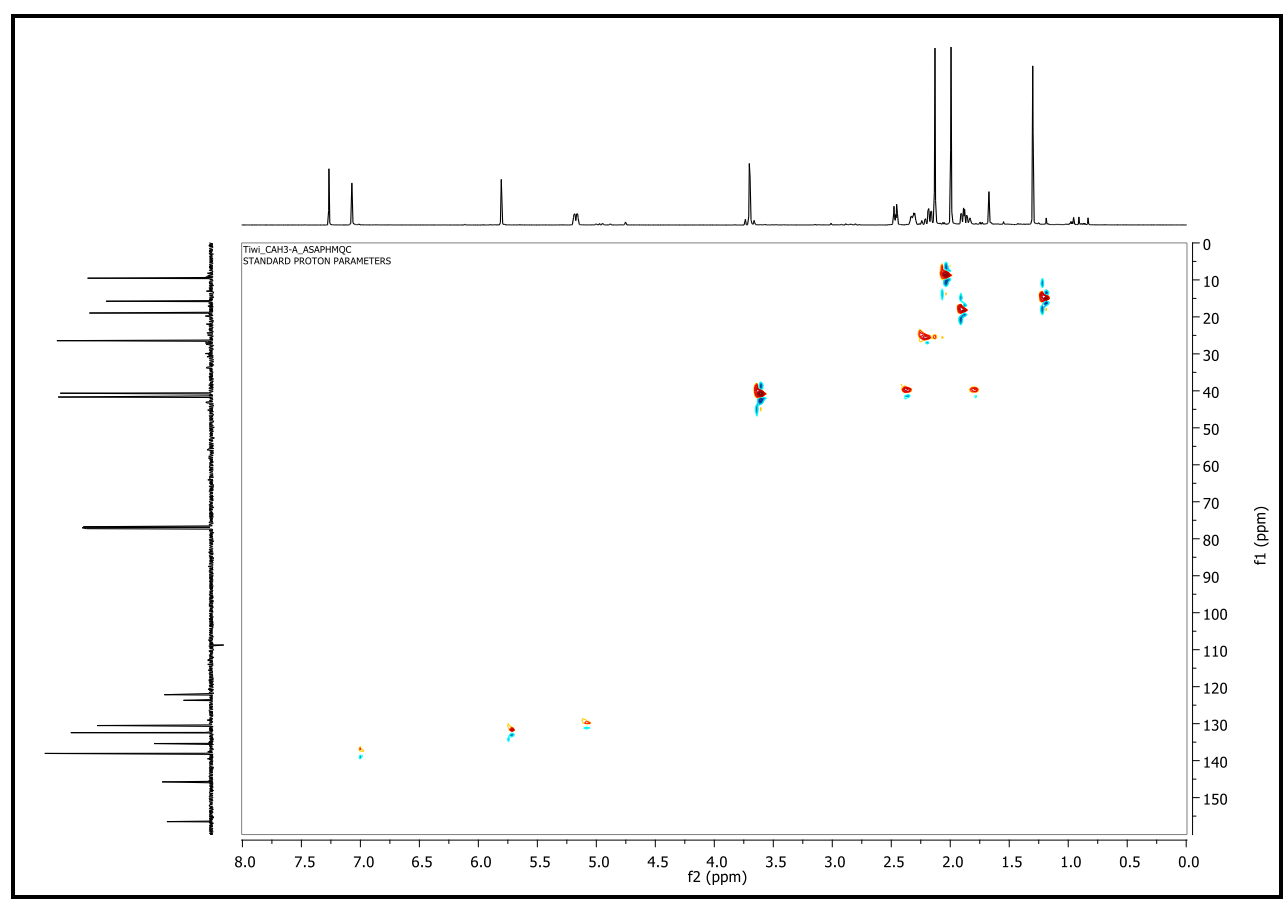

Gambar 5. Spektrum NMR 2D-HMQC

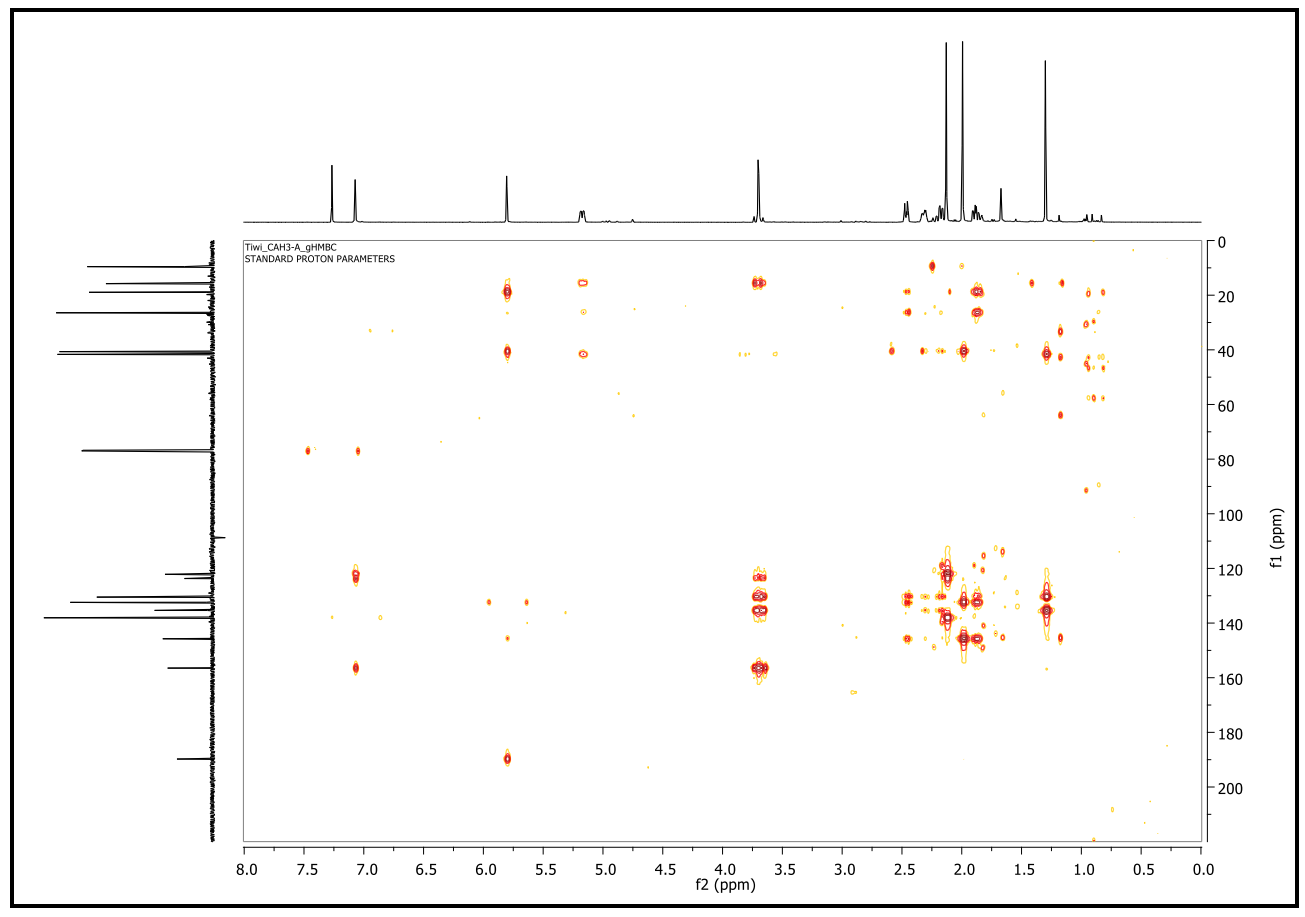

Gambar 6. Spektrum NMR 2D-HMBC 
Seskuiterpen furanodienon dari rimpang Curcuma Xanthorrizha... (Hartiwi Diastuti, dkk)

Tabel 1. Data spektrum ${ }^{1} \mathrm{H},{ }^{13} \mathrm{C}-\mathrm{NMR}$ dan $\mathrm{HMBC}$ isolat murni

\begin{tabular}{clrl}
\hline No. & \multicolumn{1}{c}{$\delta \mathrm{H}($ mult. $J \mathrm{~Hz}) \mathrm{ppm}$} & $\delta \mathrm{C} \mathrm{ppm}$ & \multicolumn{1}{c}{$\mathrm{HMBC}\left({ }^{1} \mathrm{H} \leftrightarrow{ }^{13} \mathrm{C}\right)$} \\
\hline 1 & $5,18(d d, 4,3 ; 11,1)$ & 130,51 & $\mathrm{C}-15 ; \mathrm{C}-9$ \\
2 & $2,18(m) ; 2,31(m)$ & 96,43 & $\mathrm{C}-1$ \\
3 & $1,88(m) ; 2,47(m)$ & 40,65 & $\mathrm{C}-4 ; \mathrm{C}-5$ \\
4 & - & 145,74 & - \\
5 & $5,80(s)$ & 132,43 & $\mathrm{C}-3 ; \mathrm{C}-14 ; \mathrm{C}-6$ \\
6 & - & 189,77 & - \\
7 & - & 122,17 & - \\
8 & - & 159,49 & - \\
9 & $3,70(s)$ & 41,68 & $\mathrm{C}-1 ; \mathrm{C}-10 ; \mathrm{C}-8 ; \mathrm{C}-15$ \\
10 & - & 135,37 & - \\
11 & - & 123,70 & - \\
12 & $7,05(s)$ & 138,05 & $\mathrm{C}-8 ; \mathrm{C}-11$ \\
13 & $2,13(s)$ & 9,54 & $\mathrm{C}-7 ; \mathrm{C}-12$ \\
14 & $1,99(s)$ & 18,96 & $\mathrm{C}-4 ; \mathrm{C}-5$ \\
15 & $1,30(s)$ & 15,77 & $\mathrm{C}-1 ; \mathrm{C}-10$ \\
\hline
\end{tabular}

Posisi dan korelasi atom karbon dan proton dari isolat murni dapat dilihat pada Tabel 1. Spektrum MS (Gambar 7) memperlihatkan puncak ion molekul $\left(\mathrm{M}^{+}\right) \mathrm{m} / \mathrm{z}$ 230, hal ini berarti massa molekul dari isolat murni adalah 230. Berdasarkan data-data NMR dan MS tersebut di atas, isolat memiliki rumus molekul $\mathrm{C}_{15} \mathrm{H}_{18} \mathrm{O}_{2}$, dan disimpulkan bahwa isolat adalah furanodienon $(8,12$ epoksigermakra-1(10),4,7,11-tetraen-6on) yaitu senyawa seskuiterpen germakran dengan struktur kimia seperti pada Gambar 8 berikut. Senyawa tersebut pernah dilaporkan juga terdapat dalam daun C. longa (Liu, et al., 2012) dan rimpang C. zedoaria (Ravindran, et al., 2007).

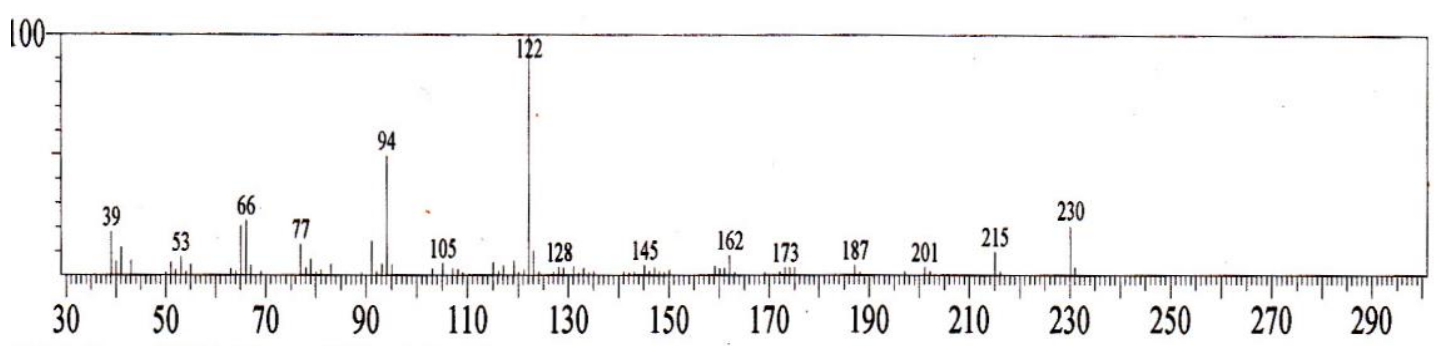

Gambar 7. Spektrum MS isolat murni<smiles>CC1=CC(=O)c2c(C)coc2CC(C)=CCC1</smiles>

Gambar 8. Struktur furanodienon 
Tabel 2. Data aktivitas antibakteri furanodienon

\begin{tabular}{lcccc}
\hline \multicolumn{1}{c}{ Bakteri } & \multicolumn{2}{c}{ Kloramfenikol } & \multicolumn{2}{c}{ Furanodienon } \\
\cline { 2 - 5 } & $\begin{array}{c}\mathrm{MIC} \\
(\mu \mathrm{g} / / \mathrm{mL})\end{array}$ & $\begin{array}{c}\mathrm{MBC} \\
(\mu \mathrm{g} / \mathrm{mL})\end{array}$ & $\begin{array}{c}\text { MIC } \\
(\mu \mathrm{g} / / \mathrm{mL})\end{array}$ & $\begin{array}{c}\mathrm{MBC} \\
(\mu \mathrm{g} / \mathrm{mL})\end{array}$ \\
\hline E. coli & 3,9 & 3,9 & 125,0 & 125,0 \\
P. aeruginosa & 3,9 & 3,9 & 125,0 & 125,0 \\
B. subtilis & 62,5 & 62,5 & 125,0 & 125,0 \\
S. aureus & 3,9 & 7,8 & 250,0 & 250,0 \\
\end{tabular}

Senyawa hasil isolasi yaitu furanodienon, selanjutnya diuji aktivitas biologinya terhadap empat bakteri yaitu E. coli, $P$. aeruginosa, B. subtilis dan $S$. aureus. Uji antibakteri dilakukan dengan metode mikrodilusi pada konsentrasi 3,9 - 500,0 $\mu \mathrm{g} / \mathrm{mL}$. Pada uji ini sebagai kontrol positif digunakan kloramfenikol dengan konsentrasi yang sama dengan sampel uji. Data hasil uji antibakteri disajikan pada Tabel 2.

Berdasarkan data di atas, furanodienon menunjukkan aktivitas antibakteri yang lebih lemah dibandingkan kontrol positifnya yaitu kloramfenikol. Aktivitas antibakteri yang lemah dari furanodienon diperlihatkan dengan nilai MIC dan MBC yang lebih besar dibandingkan kloramfenikol. Nilai MIC dan MBC furanodienon berkisar antara 125,0 sampai $250,0 \mu \mathrm{g} / \mathrm{mL}$, sedangkan nilai MIC dan MBC kloramfenikol berkisar antara 3,9 sampai $62,5 \mu \mathrm{g} / \mathrm{mL}$. Semakin kecil nilai MIC dan MBC, maka semakin tinggi aktivitas antibakterinya.

\section{KESIMPULAN}

Hasil isolasi senyawa seskuiterpen dari rimpang $C$. xanthorrhiza diperoleh senyawa murni berupa minyak tak berwarna. Berdasarkan data-data spektroskopi senyawa tersebut adalah senyawa seskuiterpen furanodienon.
Senyawa ini memiliki aktivitas antibakteri yang lemah terhadap bakteri uji dengan nilai MIC dan MBC 125,0 dan $250,0 \mu \mathrm{g} / \mathrm{mL}$.

\section{UCAPAN TERIMAKASIH}

Peneliti mengucapkan terimakasih kepada program Riset Desentralisasi (DIKTI) tahun 2012 Institut Teknologi Bandung atas bantuan dana penelitian.

\section{DAFTAR PUSTAKA}

Achmad, S.A., Hakim, E.H., Makmur, L., Syah, Y.M., Juliawaty, L.D., Mujahidin, D., 2008. Ilmu Kimia dan Kegunaan Tumbuh-tumbuhan Obat Indonesia, Jilid 1, Penerbit ITB, Bandung,

Choi, M.A., Kim, S.H., Chung, W.Y., Hwang, J.K., 2005, Xanthorrhizol, a Natural Sesquiterpenoids from Curcuma xanthorrhiza, has an Anti-metastatic Potential in Experimental, Biochemical and Biophisical Research Communication, Vol. 326, 210217.

Dalimartha, S., 2007, Atlas Tumbuhan Obat Indonesia, Jilid 2, Trubus Agriwidya, Jakarta.

Handayani, T., 2008, Pengaruh Xantorizol terhadap sel Hepatoma HepG2, Jurnal Kebangsaan Malaysia, Vol. 8, 29-35, 
Hwang, J.K., Shim, J.S., Pyun, Y.R., 2000, Antibacterial Activity of Xanthorrhizol from Curcuma xanthorrhiza against Oral Pathogens, Fitoterapia, Vol.71, 321-323,

Itokawa, H., Hirayama, F., Funakoshi, K., Takeya, K., 1985, Studies on The Antitumor Bisabolen Sesquiterpenoids Isolated from Curcuma xanthorrhiza, Chem. Pharm. Bull. (Japan), Vol. 33, 3488-3492.

Kamazeri,T.S.A.T., Samah, O.A., Taher, M., Susanti, D., Qaralleh, H., 2012, Antimicrobial Activity and Essential Oils of Curcuma aeruginosa, Curcuma mangga, and Zingiber cassumunar from Malaysia, Asian Pasific Journal of Tropical Medicine, 202-209,

Liu, Y., and Nair M.G., 2012, Curcuma longa and Curcuma mangga Leaves Exhibit Fungtional Food Property, Food Chemistry, Vol.135, 634-640.

Ravindran, P.N., Babu, K.N., Sivaraman, K., 2007, Turmeric : The Genus Curcuma, Medicinal and Aromatic Plants-Industrial Profiles, CRC Press, New York.

Rukayadi, Y., and Hwang, J.K, 2007, In Vitro anti-Malassezia Activity of Xanthorrhizol Isolated from Curcuma xanthorrhiza, Letter in Apllied Microbiology, Vol. 44, 126130.

Saleem, M., Nazir, M., Ali, M.S., Hussain, H., Lee, Y. S., Riaz, N., Jabbar, A., 2010, Antimicrobial Natural Products: An Update on Future Antibiotic Drug Candidates, Natural Product Report, Vol. 27, 238-254.

Tilaar, M., Wih, W.L., Ranti, A.S., 2010, The Green Science of Jamu :
Pendekatan Pragmatik untuk Kecantikan dan Kesehatan, Dian Rakyat, Jakarta.

Yamazaki, M., Maebayashi, Y., Iwase, N., Kaneko, T., 1988, Studies on Pharmacologically Active Principles from Indonesian Crude Drugs, Chem. Pharm. Bull, Vol.36, 2070-2074.

Yasni, S., Imaizumi, K., Sin, K., Sugano, M., Nonaka, G., Sidik, 1994, Identification of an Active Principle in Essential Oil and Hexane Soluble Fractions of Curcuma xanthorrhiza Roxb. Showing TrigilycerideLowering Action in Rats, Food and Chemical Toxicology, Vol. 32, 273-278. 